\title{
Deformed Wing Virus em Apiários do Rio Grande do Sul
}

\author{
Mariana Fonseca Costaㄹ, Maria Carolina Paleari Varião de Oliveira ${ }^{2}$, Clarissa \\ de Lima Barcelos², Andrés Delgado Cañedo \\ 12 Universidade Federal do Pampa \\ Av. Antonio Trilha, 1847 CEP: 97300000 São Gabriel-RS e-mail: \\ andrescanedo@unipampa.edu.br
}

Introdução: Vírus têm sido associados ao fenômeno mundial Colony Collapse Disorder (CCD), responsável pelo alto índice de desaparecimento de colônias de abelhas, afetando diretamente a agricultura e todas as espécies vegetais que dependem das abelhas para polinização. Dentre os vírus apontados como possível causa, encontra-se o Deformed Wing Vírus (DWV), que possui como característica principal, a deformidade nas asas dos 1847 indivíduos infectados. Esta pesquisa teve por objetivo verificar a incidência deste vírus em apiários de distintos municípios, que registraram alta mortandade de abelhas e enfraquecimento de enxames. Metodologia: Foram realizadas coletas em apiários que se mostravam com queda crescente no número de abelhas, onde foram encontrados indivíduos com claros sintomas virais. O material coletado foi levado ao Laboratório de Biologia Molecular da Universidade Federal do Pampa, campus São Gabriel, onde foram realizados os testes virais. Foram utilizados três pares de oligonucleotídeos iniciadores, um referente à região de 8500 pares de base, próximo a região $3^{\prime}$ final do genoma, outro à região de 6500 pares de base, e o outro com anelamento próximo em 2500 , próximo a região $5^{\prime}$ do genoma. O resultado final foi enviado para sequenciamento. Resultados: Obtevese resultados positivos para DWV em abelhas sintomáticas e assintomáticas, mostrando que o vírus muitas vezes pode estar presente, mas se não possuir alta taxa de infecção no indivíduo, a infecção torna-se silenciosa. Um dos primers, utilizado em trabalhos previamente publicados por outros autores, para nossas amostras não funcionou, entretanto foi possível registrar resultados positivos para o segmento inicial $5^{\prime}$ e o final 3' do genoma. Conclusões: Nossos resultados demonstram que o vírus encontrado é de fato o DWV, e não seu híbrido com o vírus da mesma família, Varroa Desctructor Virus, como já reportado em estudos prévios, e registram a presença deste vírus para apiários com alta mortalidade de indivíduos.

Palavras-chave: vírus, abelhas, DWV.

Universidade Estadual de Londrina - Rodovia Celso Garcia Cid, Pr 445, Km 380 Campus Universitário Caixa Postal 10.011 CEP 86057-970 Centro de Ciências Exatas Departamento de Bioquímica e Biotecnologia Fone +55 (43) 3371.4270 - biq@uel.br 